\title{
Influence of the entrepreneurial environment upon availability of real investments
}

\author{
Josef NOVOTNÝ ${ }^{1}$, Renáta MYŠKOVÁ ${ }^{2}$, Vít JEDLIČKA ${ }^{3}$ \\ ${ }^{1}$ University Pardubice, Pardubice, Czech Republic \\ josef.novotny@upce.cz \\ ${ }^{2}$ University Pardubice, Pardubice, Czech Republic \\ renata.myskova@upce.cz \\ ${ }^{3}$ University Pardubice, Pardubice, Czech Republic \\ vit.jedlicka@upce.cz
}

\begin{abstract}
While evaluating investments, as a rule, first of all, investing criteria, which include yield, risk and liquidity, are being assessed. This step is usually performed by most of beginning and unprofessional investors. The goal of the paper is to draw attention the criterion which it is necessary to take into consideration while making decision about investment intentions as first, and by this - to describe a method of its assessment. It comes from economic conditions, where each investor has a limited quantity of financial resources which is a limiting factor for him/her. The main problem is that a series of beginning investors is excited by whatever financial product and considers its future purchasing just to discover - after a certain period of time - that only part of solvent investors, who has a sufficient initial financial capital, is able to enter this field of investments. The benefit is that there are such investment products in the entrepreneurial environment the conditions of which can be adjusted so that they were maximally available for the general public. On the contrary, some other investments, however, precisely define a quantity and the minimal amounts which are to be at the investor's disposal by the date of investment realization.
\end{abstract}

Keywords: Availability, Real investment, Entrepreneurial environment.

\section{Introduction}

Everyone who has made decision to carry out investment intentions should have a sufficiency of his/her own financial recourses of which he/she is ready to give up at a certain moment with the expectation that in the future - owing to the performed investments - they will be increased in value, and at the same time their possible loss will not threaten the quality of his/her life. There is, however, part of investors who borrow a foreign capital for their business transactions, which is very hazardous and unadvisable because it can decrease the life level and bring to financial difficulties 
from which they can escape just after a long time and with an impact to the investor's personal life, which could result even in a personal bankrupt. It is necessary to be aware that each investment contains a certain measure of risk. Investments can be perceived by investors both positively and negatively; a series of objective and subjective factors participate in the overall feeling (Myšková, Hájek, 2016). The positive impacts express themselves positively in the investors' behavior because they bring to the increase of property assets, to the sense of happiness, satisfaction, euphoria, and the investors then continue working in other business activities. By contrast, negative impacts have absolutely opposite consequences which manifest themselves in increasing fear, uncertainty, pessimisms and can even result in an absolute termination of investing in financial markets. A certain benefit is that the present-day financial markets offer a wide spectrum of investment products. Investor may choose some of them and create investment portfolios from these investments, which bring to the decrease of the risk.

The target of this paper is to call attention to the often-neglected criterion, i.e. an availability of an investment for the investing public, and to describe a method of its evaluation. The main problem is that a series of beginning and unprofessional investors is excited by any investment product and talk about how they would perform their investment intentions in order to discover later that they do not have a sufficient initial financial capital and - because of it - they cannot enter the field of investments. Although the entrepreneurial environment modifies some of the investment products so that they were maximally available to the general public, there are certain investment products which are only available for highly-solvent groups of citizens, and there is no corresponding investment available for the general public.

Each investment has its own specifics. It is also valid for real investments which are accepted in this paper. There are investments which have just a capital yield. It is typical for precious metals and stones in a real form. The questions of precious metals are dealt with by, for example, Eryigit (2017), Fauzi, et al. (2017), Almudhaf and AlKulaib (2017). Some investors, however, give priority to financial investments which pay out an additional yield by means of dividends, and - accordingly - prefer in principle only such companies which guarantee a reliable dividend policy (Sejkora, Duspiva, 2015), that's why they do not deal with real investments at all. Altman (2000), Kuběnka (2015) and others recommend using - while evaluating the risk of investment into a company - the financial bankrupt models which do not consider the dividend policy at all. Today's entrepreneurial environment with the support of financial engineering, however, creates and modifies investments so that they were available for the very general investing public. These modifications express themselves in the case of real investments by the sizes, dimensions, quantities of a precious metal and so on.

\section{Availability of investments for investors}

Most of unprofessional and beginning investors - prior entering any investment field - perform analysis of possible yields \& risks and possible liquidity, but do not locate 
availability of the investment which is crucial for investments. In the case of investment intentions in real investments, the issue of investment availability is appropriate, and is derived from the market price of the asset, which is different at the given moment. Novotný (2018, pages 24-25) divides availability into three levels: high, middle and low. High availability means that the general public can acquire the investment; middle availability determines a medium and higher income group, that's why this investment product is not available for the wide range of investors because there is a higher financial barrier here for the low-income part of the public. The last level of availability is created by the high-income group which is the smallest and which can buy investment products which are not accessible for the above-mentioned groups. This availability is expressed by the Investor's Triangle of Availability, which is shown on Figure 1.

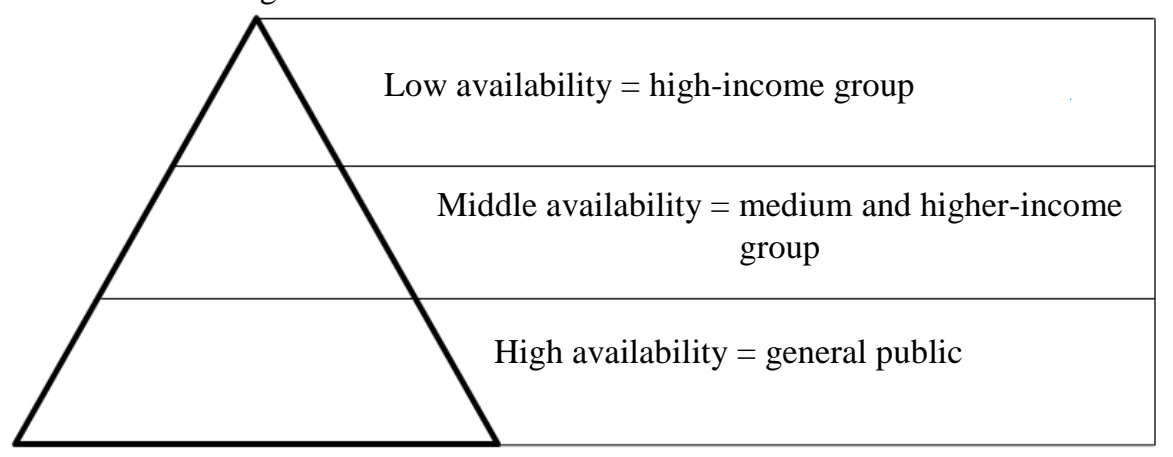

Fig. 1. Investor's Triangle of Availability. Source: Novotný (2018)

Investment availability is closely associated with compilation of an investment portfolio which is influenced by the economic conditions of each individual, and also with other attributes such as an approach to risk, to a required yield and to investment instrument's liquidity. Some authors, such as Froot et. al., (2001) and Poshakwale and Thapa (2011) emphasize that it is worth to have a portfolio and that it is a good idea to invest in several different investment instruments both in the domestic market and at the international level. At the present, the assortment of the investment products owing to the globalization processes - is enormous. An investor now can choose not only an investment instrument but also a country and continent where he/she is going to perform his/her investment intentions. These processes influence an expansion of availability of the products having a global character.

\section{Analysis of the influence of the entrepreneurial environment upon availability of real investments}

In order to reach the set goal, the current business environment is characterised from the investor's point of view, using macroeconomic variables, such as the unemployment rate, inflation rate and the average and minimal wage. Based on calculation of possible savings, there are defined boundaries of availability for 
particular groups of investors, and investment possibilities related to real investment instruments are also shown in a form of case studies.

Owing to the entrepreneurial environment, it is possible to modify investment products so that they were available for maximum number of investors. The higher availability is, the greater number of investors has a possibility to purchase such an investment product and to create compositions of investments, reducing - by this $-\mathrm{a}$ risk of loss. The following model cases show a price availability of selected real investments and their combinations providing that - according to Novinky (2018) an average Czech person saves up CZK 3,600 monthly, it means CZK 43,000 per year. This amount of the saved financial resources represents high availability. Middle availability comes from the amount of the average wages and assumes monthly savings on the part of investors up to CZK 30,000, i.e. CZK 360,000 annually; and low availability was defined above the level of the average wages, i.e. about the boundary of CZK 30,000 per month, it means more than CZK 360,000 per year. Seeing that the Czech Republic economics has been growing for already five years in a row, it positively expresses itself in a growth of incomes of private households. The average wage reached around CZK 30,000 in the first quarter of 2018 , which is accompanied by a low inflation rate below $2.5 \%$ over same period. (according to the Czech Statistical Authority, 2018) in the first quarter of 2018. And the minimum wages respond to it by growing. It reached CZK 12,000 from 1st January 2018. Compared with 2017, it has grown by CZK 1,200 from the original amount of CZK 11,000. It means relative annual growth almost of $11 \%$. It consequently results in low fears of losing job because the Czech Republic has the lowest unemployment level in the whole European Union, which reaches $3.1 \%$. And this increases tendency to investing. (MPSV, 2018) The below-mentioned model cases don't include charges and other transaction costs related to the investment intentions.

As for the assortment of real investments in the Czech Republic, it is possible to invest in precious metals, precious stones, estates, real properties and alternative investments. The following Triangle of Investment Availability is compiled from selected real investments offered in the territory of the Czech Republic, into which an investor can invest under certain economic conditions. These conditions have a fundamental influence upon the assortment of real investments in particular parts of availability. The better economic conditions of an individual are, the higher a selection of investments is; whereas the greatest number of them is in the low level and the lowest number of them is in the high level of availability. 


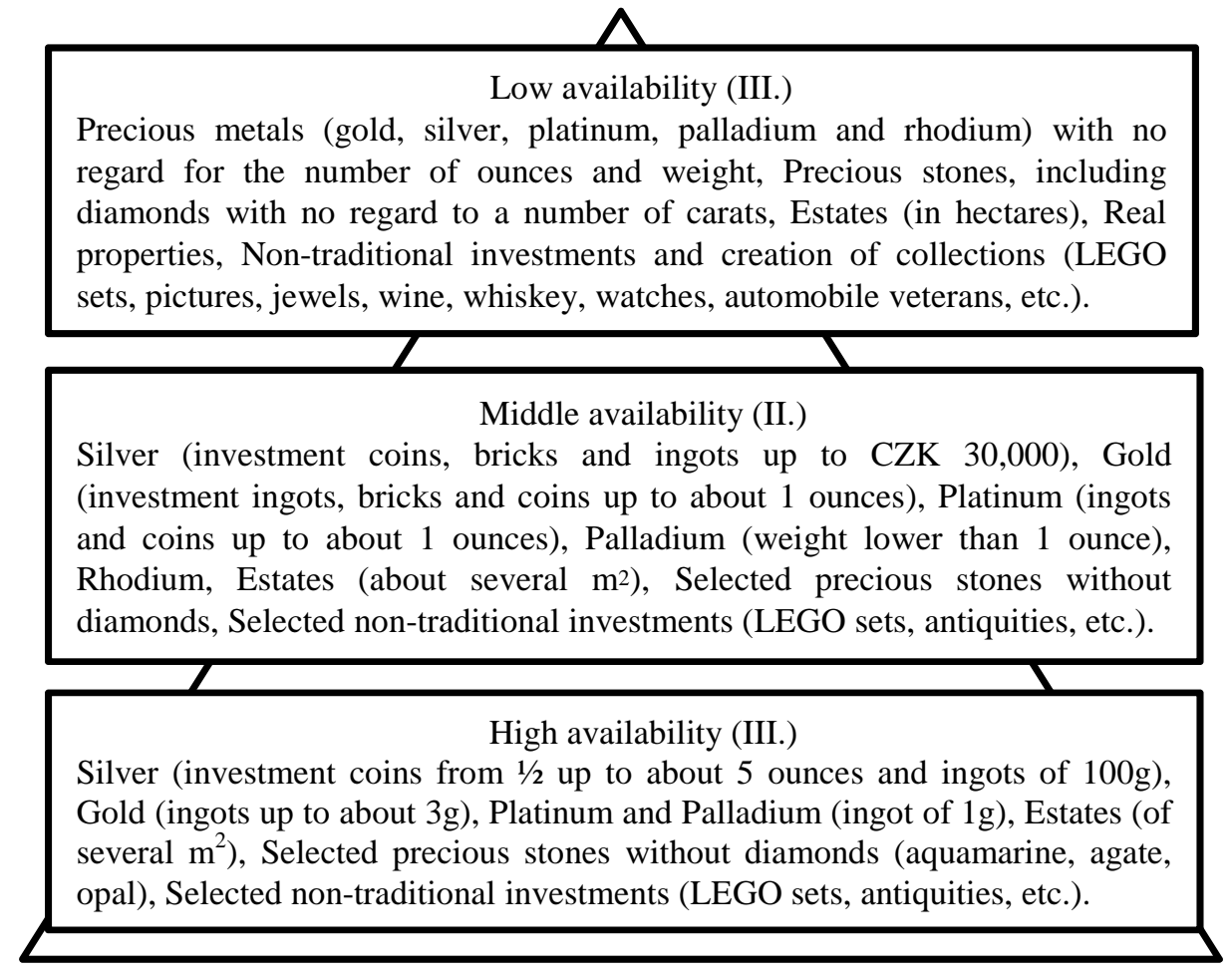

Fig. 2. The Triangle of Availability compiled from selected real investments. Source: Authors' processing according to Novotný (2018)

As can be seen from Figure 2, the entrepreneurial environment creates certain investment conditions for all income groups. In the case of precious metal, it is, first of all, a possibility to invest in silver - here is a significantly wide offer even for nonprofessional investors. It is possible to perform relatively extensive investment intentions and to create, thus, collections based on this precious metal in the future.

Possibilities of investing for small investors (group I.) can be shown via the following case study. Supposing savings of CZK 3,600 per month, an investor may purchase, for example, a silver Argor-Heraeus 100g ingot for CZK 1,791 and two one-ounce (remark: Troy ounce) Australian Swan investment coins for the price of CZK 1,335 and Australian Kookaburra for CZK 474. (Auportal, 2018). The investor would begin realization of his/her strategic intention in silver by this investment decision. Such a decision related to the type of real investment can be considered to be well-founded because quantity of silver is less than gold and it is metal which has an unsubstitutable position in the industry. It is however possible to carry out other transactions than just with silver or other metals.

Here is also a possibility of other non-traditional investments such as, for example, LEGO. The LEGO for a Czech investor is very well-known company, and it is also valid for its toys which can be bought in a wide network of stone shops as well as in e-shops, so their availability from the point of view of their purchasing is significantly 
higher than availability of precious metals (a number of sale-points for precious metals is considerably lower). In the case of LEGO toys, it is a relatively nondemanding investment with regards to a necessity of initial capital, and the age of the investment plays no role here. LEGO sets which bear "exclusive" sign, can hardly be found and is going to be excluded from the assortment on the market soon are suitable for investing. As an example of suitable products of LEGO Company for small investors can be two products marked as exclusive and with the price lower than CZK 3,600 , namely: The railway station in a snowy village (CZK 1,799) and the Fire station in a winter village (CZK 2,399). (LEGO, 2018) No other costs are, in principle, related with this investment, because what must be only ensured is to provide preservation of the product without damaging (it means to ensure suitable storage conditions).

It is also possible to carry out investments in precious stones, but it can be only suitable for a limited group of investors, because the market is less liquid, even in comparison with the precious metal market. Beside of that, small investors don't own sufficient capital and at the present time there might be a risk of buying imitation in the case of processed stones. Small investors underestimate verification of stone authenticity, maybe by reason that they don't want to increase their purchase price.

Investments in estates are not also suitable for investors with a minimum free capital, because the purchase of several square meters is only suitable for own needs and for managing these lands, but not for investment intentions - purposeful estates with an area more than 10 hectares are only suitable for such intentions.

Another case study is focused on the middle availability (group II.). These are investment intentions which reflect a higher liquidity and yield due to a higher assortment of products into which an investor can invest. Speaking of precious metals, it is possible to choose, for example, gold. An investor may purchase a oneounce coin which is more liquid than $1 \mathrm{~g}$ of bare metal. As an example, it is possible to buy gold coins of American Eagle (CZK 28,793), American Buffalo (CZK 29,909) and Canada's Maple Leaf (CZK 28,462). Possibilities of investment in platinum are also extended, where it is possible to purchase one-ounce investment coin, for example, Britannia 2018 (CZK 26,438) and further investment bricks, for example, of Pamp 5g (CZK 5,712). In the case of selection of investment in palladium, it is possible to invest in products with a weight lower than one Troy ounce such as, for example, a 10g Pamp brick (CZK 11,462). The investment intentions for this group of investors are also extended by precious investment metal - rhodium, whereas it is possible to purchase a $1 / 4$ ounce Bairds UK brick for CZK 21,842. (Zlaté-investování, 2018) Investments in precious stones also provide other possibilities. It is possible to purchase several-carat products, where their purchase price is higher than CZK 3,600 - for example, blue topaz - 3,35 carats (CZK 7,440), purplish red ruby of 0,94 carat (CZK 6,895), light green emerald of 3,39 carat (CZK 14,159) and others. (VVDIAMONDS, 2018) Transactions with lands are also more accessible, however their investment potential has no sense for the investment purposes now, and it can be more likely purchased for own needs. The benefit of this group of investors is that a portfolio of non-traditional investments is being extended, for example, by valuable antiquities such as a Girl on a House statuette (CZK 8,900), author of which is Grath 
Anton. (Antik-galerie, 2018) Middle availability is connected with a higher free capital of the investor, so an extension of investment opportunities to more investments enables decreasing the portfolio risk.

Low availability of investments is connected with the lowest number of investors who, however, can invest in the highest number of investment instruments. They then may extend their portfolio by investment products which most of investors cannot reach to.

A suitable investment during last years were estates (a land with an area of 10 hectares and higher is suitable for investing), because their prices was growing every year. At the present time, an average market price of one hectare of agriculture land is CZK 235,100 (Farmy, 2018); but the question is whether the prices couldn't stop growing, because the market price is very different from the official price (owing to the provided donations to such entities who manage the land). An interesting investment opportunity is the purchase of a real property for the purpose of its renting or future sale. With respect to strengthening the conditions for gaining a loan for housing, there will be permanent interest for the rent of real properties. These investors (group III.) may also include investment diamonds into their portfolio of precious metals, for example, 1,040 carat-diamond for the price of CZK 228,569. (VVDIAMONDS, 2018) Their portfolio of non-traditional investments is also significantly extended, because the minimum recommended investment, for example, in investment stamps is from a half-million of CZK, in wine from CZK 250,000 and so on. A benefit of these investors is a high diversification of risk, a possibility to invest in real instruments which for a series of citizens are unavailable with regards to their financial possibilities, and, by this, reaching higher yields.

\section{Discussion}

For all investments, no matter if it is financial or real, primary investment criteria are to be evaluated, however it is necessary to remember that it is impossible to firstly evaluate yield, risk and liquidity unless the investor's financial situation is cleared-up in advance. Not earlier than after detection of the economic situation, investment products accessible and suitable for him/her can be offered.

Real investments, as a rule, have lower riskiness compared to the financial investments, however this higher risk is connected with their higher possible yield. On the other hand, it is beneficial if investors at least part of their financial means invest in real assets and diversify, by this, their risk. The benefit is that the entrepreneurial environment is disposed toward investments and creates investment opportunities so that it modifies part of products in order to ensure their availability for the general public. The problem, which was sketched in this paper, is insufficient knowledge of availability of investments, especially among small investors who do not have enough information on the investment instruments. The assortment of real products thus continues to be limited, and investment intentions are not being extended, especially on the part of small investors. The above-mentioned case studies are therefore determined, first of all, for this group. On the basis of the limitation of 
certain extreme values of the free capital, investment possibilities for another, financially stronger, investors were also shown.

A big problem of the Czech environment is - both from theoretical a practical point of view - absence of purposeful literary sources focusing on some types of real investments such as platinum, palladium, rhodium and alternative investments as a whole. This paper may contribute to increasing consciousness of real investments and, by this, support origination of investment intentions in real - maybe even less popular - investments. For completeness' sake, it is necessary to mention that not only own sources can be, of cause, used for investing but it is possible to use also a foreign capital. In this case, it is necessary to assess costs for the foreign capital compared to the investment's rate of profit.

\section{Conclusion}

A decision to perform investment intentions in real investments has to be derived from financial possibilities of the investor, what limits the assortment of these instruments. Each beginning investor should invest in such instruments which he/she at least a little understands or which he/she will chose on the basis of recommendations of an expert having proper experience. It is the only way how to eliminate risk. Investors are divided into three groups depending availability of investments, namely on the basis of their financial possibilities. It doesn't mean that an investor has no chance to move within the specified groups; a positive change of his/her economic conditions can be enough, which can be a result of his/her career growth in job, inherited property, etc. The investor also doesn't need to purchase investments regularly (monthly, quarterly), but he/she can only invest once a year or once a more years, what will enable him/her to save more financial resources and purchase an investment instrument with a higher purchase price. No investment instrument guarantees reaching the expected yield, however real investments are historically connected with a certain sentiment, so their riskiness can be considered lower compared to shares and other financial instruments. The current entrepreneurial environment is favorable for the real investments.

\section{Acknowledgements}

This contribution was made with the financial support of SGS_2018_013.

\section{References}

1. Almudhaf, F., AlKulaib, Y.: Market timing in precious metals is detrimental to value creation. Applied economics letters, 24(14), 1019-1024 (2017). DOI: 10.1080/13504851.2016.1248280

2. Altman, E.: Predicting Financial Distress of Companies: Revisiting the Z-score and ZETA Models [working paper]. Stern School of Business, New York (2000).

3. Antik-galerie. https://antik-galerie.cz/homepage/item/286, URL, last accessed 2018/09/24 
4. Auportal. https://www.auportal.cz/, URL, last accessed 2018/10/01.

5. Český statistický úřad. https://www.czso.cz/csu/czso/domov, URL, last accessed 2018/06/04.

6. Eryigit, M.: Short-term and long-term relationships between gold prices and precious metal (palladium, silver and platinum) and energy (crude oil and gasoline) prices. Economic research-ekonomska istrazivanja, 30(1), 499-510 (2017). DOI: 10.1080/1331677X.2017.1305778

7. Farmy: Zpráva o trhu s půdou, http://www.farmy.cz/dokumenty/ZPRAVA-o-trhu-s-pudouFARMYCZ-leden-2018.pdf, 2018/01/20.

8. Fauzi, A., W., A., Husniyah, A., R., Fazli, S., M, Amim, O., M.: Financial Risk Tolerance as a Predictor for Malaysian Employees' Gold Investment Behavior. Regional studies on economic growth, Financial economics and management, 7, 63-76 (2017). DOI: 10.1007/978-3-319-54112-9_5

9. Froot, A., K., O'Connell, G. J. P., Seasholes, S. M.: The portfolio flows of international investors. Journal of Financial Economics, 59(2), pp. 151-193 (2001). DOI: 10.1016/S0304-405X(00)00084-2

10. Kuběnka, M.: Predictive Ability of the Index of Creditworthiness. In Proceedings of the 7th International Scientific Conference Finance and Performance of Firms in Science, Education and Practice. Zlín: Univerzita Tomáše Bati ve Zlíně, Zlín pp. 795-804 (2015).

11. Lego. https://shop.lego.com/cs-CZ/Nove-exkluzivni, URL, last accessed 2018/09/30.

12. Ministerstvo práce a sociálních věci (MPSV). https://portal.mpsv.cz/upcr/kp/pak/nezamestananost_v_cislech, URL, last accessed 2018/08/31.

13. Myšková, R., Hájek, P.: The Effect of Managerial Sentiment on Market-to-Book Ratio. Transformations in Business and Economics, 15(2A), pp. 498-513 (2016).

14. Novinky. https://www.novinky.cz/finance/480628-cesi-v-prumeru-za-rok-naspori-43-tisickorun.html, URL, last accessed 2018/08/24.

15. Novotný, J.: Investování na finančních trzích s podporou psychologické analýzy. Vydání první. Key Publishing, Ostrava (2018).

16. Poshakwale, S. S., Thapa, Ch.: Investor protection and international equity. Global finance journal, 22(2), pp. 116-129 (2011). DOI: 10.1016/j.gfj.2011.10.003

17. Sejkora, F., Duspiva, P.: The Position of Management of Czech Joint-Stock Companies on Dividend Policy. Economics and Management, 18(2), 73-88 (2015). DOI: 10.15240/tul/001/2015-2-006

18. VVDIAMONDS. https://www.vvdiamonds.cz/, URL, last accessed 2018/09/30.

19. Zlaté-investování. https://www.zlate-investovani.cz/, URL, last accessed 2018/09/20. 